\title{
APPLICATION OF FTIR SPECTRA COMBINED WITH CHEMOMETRICS FOR ANALYSIS OF CANDLENUT OIL ADULTERATION
}

\author{
FITRI YULIANI'1, SUGENG RIYANT01, ABDUL ROHMAN ${ }^{1,2 *}$
}

${ }^{1}$ Faculty of Pharmacy, Gadjah Mada University, Yogyakarta 55281 Indonesia, ${ }^{2}$ Research Center of Halal Products, Gadjah Mada University, Yogyakarta 55281 Indonesia

Email: abdulkimfar@gmail.com

Received: 09 Jul 2018, Revised and Accepted: 26 Jul 2018

ABSTRACT

Objective: The aim of this study was to use FTIR spectroscopy in combination with chemometrics techniques for quantification and classification of candlenut oil ( $\mathrm{CnO}$ ) from oil adulterants, namely sunflower oil (SFO), soybean oil (SyO), and corn oil (CO).

Methods: The spectra of all samples were scanned using Fourier Transform Infrared (FTIR) Spectrophotometer using attenuated total reflectance (ATR) as sampling technique at mid infrared region (4000-650 $\mathrm{cm}^{-1}$ ). Multivariate calibrations of principle component regression (PCR) and partial least square regression (PLSR) were used for quantitative models to predict the levels of CnO in the binary mixtures with SFO, SyO, and CO.

Results: The results showed that $\mathrm{CnO}$ in SFO was best quantified using PCR at wavenumbers region of $3100-2800 \mathrm{~cm}^{-1}$. Quantitative analysis of CnO in SyO was carried out using PLSR with normal spectra mode using combined wavenumbers of $1765-1625$ and $839-663 \mathrm{~cm}^{-1}$, while CnO in CO was analyzed quantitatively using normal spectra at wavenumbers of $970-857 \mathrm{~cm}^{-1}$. The coefficient of determination (R $\mathrm{R}^{2}$ obtained were $>0.99$ with low values of root mean square error of calibration (RMSEC) and root mean square error of prediction (RMSEP). The results of discriminant analysis revealed that authentic $\mathrm{CnO}$ can be discriminated from $\mathrm{CnO}$ adulterated with $\mathrm{SFO}$, SyO and $\mathrm{CO}$ using selected wavenumbers.

Conclusion: FTIR spectroscopy combined with chemometrics could be used as rapid and reliable method for authentication of candlenut oil (CnO) adulterated with other oils.

Keywords: Infrared spectroscopy, Chemometrics, Patchouli oil, Adulteration

(C) 2018 The Authors. Published by Innovare Academic Sciences Pvt Ltd. This is an open access article under the CC BY license (http://creativecommons.org/licenses/by/4.0/) DOI: http://dx.doi.org/10.22159/ijap.2018v10i5.28372

\section{INTRODUCTION}

Aleurites moluccana L., widely known as "kemiri" in Indonesia, "buah keras" in Malaysia, "candlenut" in English and "Kukui nut" in Hawaii is a flowering tree with up to $20 \mathrm{~m}$ in height, belongs to the family of Euphorbiaceae [1]. This plant is native to the region of IndoMalaysia and become one of the world's great domesticated multipurpose trees. Candlenut oil ( $\mathrm{CnO}$ ) obtained from the seeds was taken into account as excellent material in the industries of cosmetics, soap, and pharmaceuticals [2]. It is estimated that the annual production of $\mathrm{CnO}$ is approximately $3200 \mathrm{~kg} / \mathrm{ha}$ [3].

The price of candlenut oil ( $\mathrm{CnO}$ ) in the fats and oils industry, especially in Indonesia, is 10 times higher than that of other common edible oils like sunflower oil (SFO), soybean oil (SyO) and corn oil (CO), therefore, some unethical seller try to blend $\mathrm{CnO}$ either unintentionally or intentionally with cheaper oils to get economical profits [4]. Therefore, analytical methods capable of detecting the adulteration practice of high priced oils like $\mathrm{CnO}$ must be developed. Several methods based on physico-chemical and molecular biological properties have been reported for authentication of fats and oils. Such methods are differential scanning calorimetry [5], electronic nose [6], highperformance liquid chromatography with several detectors [7, 8], gas chromatography [9], capillary electrophoresis [10], nuclear magnetic resonance [11] and real-time polymerase chain reaction [12]. These methods are complex in instrumentation and need skilled analyst. For this reason, rapid quantitative analysis based on spectroscopic methods such as Fourier transform spectroscopy (FTIR) should be continuously developed.

FTIR spectrophotometry measures the functional group vibrations as a consequence of electromagnetic radiation with sample to generate a spectrum with fingerprint properties [12]. This techniques offer qualitative and quantitative analyses of targeted samples including pharmaceutical products $[13,14]$.

FTIR spectroscopy, especially in combination with chemometrics techniques, is one of the vibrational spectroscopic methods commonly used for rapid authentication analysis [16]. FTIR spectroscopy coupled with chemometrics have been used for authentication of extra virgin olive oil [17, 18], black seed oil [19], and avocado oil [20, 21], sesame oil adulterated with corn oil [22], and authentication of virgin coconut oil [23]. However, using literature searching there are no publication reports regarding the application of FTIR spectroscopy for authentication of candlenut. Therefore, the objective of this study was to use FTIR spectroscopy in combination with chemometrics for authentication of candlenut oil ( $\mathrm{CnO}$ ) with soybean oil (SyO), sunflower oil (SFO) and corn oil (CO).

\section{MATERIALS AND METHODS}

\section{Materials}

The seeds of $A$. moluccana was cut into small to fasten drying process and to increase the yield of oil. A-250 gram of cut seeds was dried into conventional oven at $90{ }^{\circ} \mathrm{C}$ for $90 \mathrm{~min}$. The seeds were pressed such a way that its oil was extracted. The candlenut oil obtained was then filtered and centrifuged to separate oil from the impurities. Soybean oil, sunflower oil, corn oil, coconut oil, argon oil, peanut oil, rice bran oil, extra virgin olive oil, palm oil and sesame oil were purchased from supermarket around Yogyakarta, Indonesia. All chemicals and reagents used were of pro-analytical grade purchased from E. Merck (Darmstadt, Germany).

\section{Analysis of fatty acid composition}

Fatty acid composition of candlenut oil and oil adulterants (sunflower, soybean and corn oils) were analyzed using gas chromatography with flame ionization detector (GC-FID). Before being injected into GC-FID, the oil samples were subjected to derivatization using sodium methoxide and $\mathrm{BF}_{3}$. The analytical procedure and GC-FID condition for analysis of fatty acid composition can be seen in Che Man et al. [24]. The identification of fatty acid was performed based on retention times of corresponding fatty acids present in samples with those in standards of fatty acid methyl esters from Sigma (Aldrich, USA). Quantification of each fatty acids was carried using internal normalization technique as in Nurrulhidayah et al. [22]. 


\section{Quantitative analysis of candlenut oil using FTIR spectroscopy}

Quantitative analysis of candlenut oil ( $\mathrm{CnO}$ ) in binary mixture with soybean oil (SyO), sunflower oil (SFO) and corn oil (CO) was facilitated with two multivariate calibrations, namely principle component regression (PCR) and partial least square regression (PLSR) by developing prediction models, either in calibration or validation. The calibration samples were prepared by mixing $\mathrm{CnO}$ with SFO, SyO and CO in the concentration range of $0-100 \%$. For validation model, another independent samples with similar composition were also prepared. All samples (calibration and validation) were scanned using FTIR spectrophotometer.

\section{Classification of $\mathrm{CnO}$ and $\mathrm{CnO}$ adulterated with other oils (SFO,} Sy0 and CO)

Qualitative analysis of $\mathrm{CnO}$ adulterated with other edible oils (SFO, $\mathrm{SyO}$ and $\mathrm{CO}$ ) was carried out by making a classification between $\mathrm{CnO}$ and $\mathrm{CnO}$ adulterated with SFO, SyO and CO using discriminant analysis (DA). During DA, a training sets of pure $\mathrm{CnO}$ and $\mathrm{CnO}$ adulterated with SFO, SyO and $\mathrm{CO}$ at concentration range of 1-50\% was prepared. All $\mathrm{CnO}$ and $\mathrm{CnO}$ mixed with SFO, SyO and CO were assigned as "authentic" and "adulterated", respectively.

\section{FTIR spectra measurement}

The measurement of FTIR spectra of samples were done using FTIR spectrophotometer (Nicolet 6700 from Thermo Nicolet Corp., Madison, WI) equipped with detector of deuterated triglycine sulphate (DTGS). This instrument was connected to computer operating systems which include OMNIC operating system (Version
7.0 Thermo Nicolet) software. The sampling compartment was horizontal Attenuated Total Rlectance kit (HATR, Smart ARK, Thermo Electron Corp.) composed of ZnSe crystal. FTIR spectra were scanned at wavenumbers of $4000-650 \mathrm{~cm}^{-1}$, using 32 scans with $4 \mathrm{~cm}^{-1}$ resolution, as absorbance mode.

\section{Data analyses}

TQ Analyst $\mathrm{T}^{\mathrm{TM}}$ software version 6 from Thermo electron Corporation (Madison, WI, USA) was used during data analysis, including multivariate calibrations and discriminant analysis. FTIR spectral regions where the variations existed were chosen for analysis.

\section{RESULTS AND DISCUSSION}

For selection of edible oils which are potential as adulterants in $\mathrm{CnO}$, principal component analysis (PCA) was used. PCA is one of chemometrics techniques commonly used for the classification of oils with similar chemical properties. PCA was performed using absorbance values at 11 wavenumbers of $3009,2923,2853,1743$, 1657, 1463, 1377, 1241, 1159, 1097, 915, and $721 \mathrm{~cm}^{-1}$. Fig. 1 revealed PCA score plot of $\mathrm{CnO}$ and other vegetable oils, representing the projection of evaluated samples defined by PC 1 (the first principle component) and $\mathrm{PC} 2$ (the second principle component). PC1 and PC2 showed the most variation among variables used during PCA. Based on PC1 and PC2 scores, soybean oil (SyO), sunflower oil (SFO) and corn oil (CO) have the closer distance to $\mathrm{CnO}$, indicating the close similarity between $\mathrm{CnO}$ with $\mathrm{SFO}$, SyO and $\mathrm{CO}$ in terms of FTIR spectra, therefore, SFO, SyO and $\mathrm{CO}$ were selected as oil adulterants in $\mathrm{CnO}$.

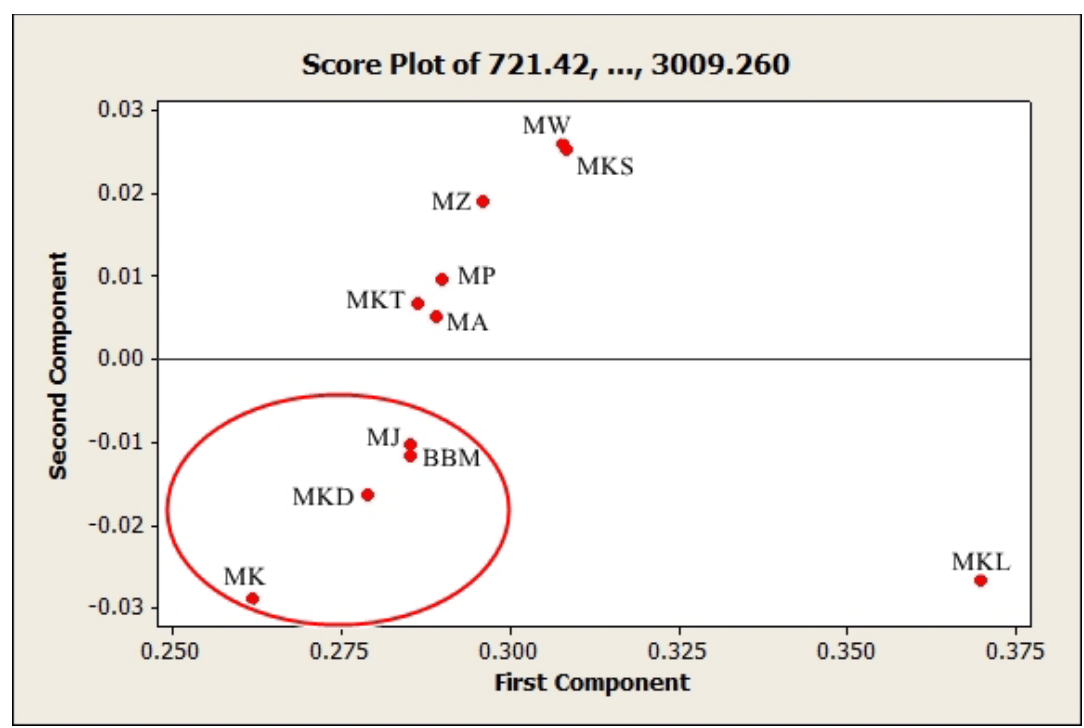

Fig. 1: The PCA sore plots of first principle component (PC1) and second component (PC2) of candle oil (CnO) and other edible oils. Sy0 = soybean oil; $\mathrm{SFO}=$ sunflower oil; $\mathrm{CO}=$ corn oil; $\mathrm{CoO}=$ coconut oil; $\mathrm{ArO}=$ argon oil; $\mathrm{PeO}=$ peanut oil; $\mathrm{RBO}=$ rice bran oil; $00=$ olive oil; $\mathrm{PaO}$ $=$ palm oil; and $\mathrm{SeO}=$ sesame oil

In order to assure that the used oil adulterants were not mixed with other oils, fatty acid composition was used for its characterization. Stearic (C18:0), linoleic (C18:2) and oleic acids were main fatty acids composed $\mathrm{CnO}$ accounting of $42.28,26.32$ and $23.12 \%$, respectively. In addition, linoleic, oleic and palmitic acids were dominant fatty acids composed SFO accounting of $67.80,19.05$, and $6.27 \%$, respectively. Linoleic and oleic also main fatty acids composed corn oils, i.e. 59.08 and $25.86 \%$, respectively. SyO was characterized by linolenic acid accounting of $8.05 \%$. These fatty acids are in agreement with those appeared in Norulaini et al. [25] and Che Man et al. [23]. This indicated that the used oils were not added with other oils.
Fig. 2 revealed FTIR spectra candlenut oil, sunflower oil, corn oil and soybean oil scanned using FTIR spectroscopy at mid infrared region (4000-650 $\left.\mathrm{cm}^{-1}\right)$ which were characteristic to triacilglyceride of infrared absoption. The interpretation of each peakas can be seen in LermaGarcia et al. [15] and Rohman [13]. The main functional groups were: (a) cis $\mathrm{CH}=\mathrm{CH}$ stretching vibration appeared in wavenumbers $(1 / \lambda)$ of 3008 $\mathrm{cm}^{-1}$, (b) $-\mathrm{CH}_{3}$ stretching vibration in $1 / \lambda$ of $2953 \mathrm{~cm}^{-1}$, (c) $-\mathrm{CH}_{3}$ stretching vibration in $1 / \lambda$ of $2953 \mathrm{~cm}^{-1}$, (d) very intense absorption of carbonyl $(\mathrm{C}=0)$ stretching vibration at $1 / \lambda$ of $1741 \mathrm{~cm}^{-1}$, (e) $1460 \mathrm{~cm}^{-1}$ corresponding to $\mathrm{CH}_{2}$ bending, (f) $1378 \mathrm{~cm}^{-1}$ due to $\mathrm{CH}_{3}$ bending, while (g) at $1235 \mathrm{~cm}^{-1}$, (h) at $1159 \mathrm{~cm}^{-1}$, (i) at $1118 \mathrm{~cm}^{-1}$, (j) at $1098 \mathrm{~cm}^{-1}$ were corresponding to $\mathrm{C}-\mathrm{O}$ stretching. All these functional groups are present in triglyceridic compounds. 


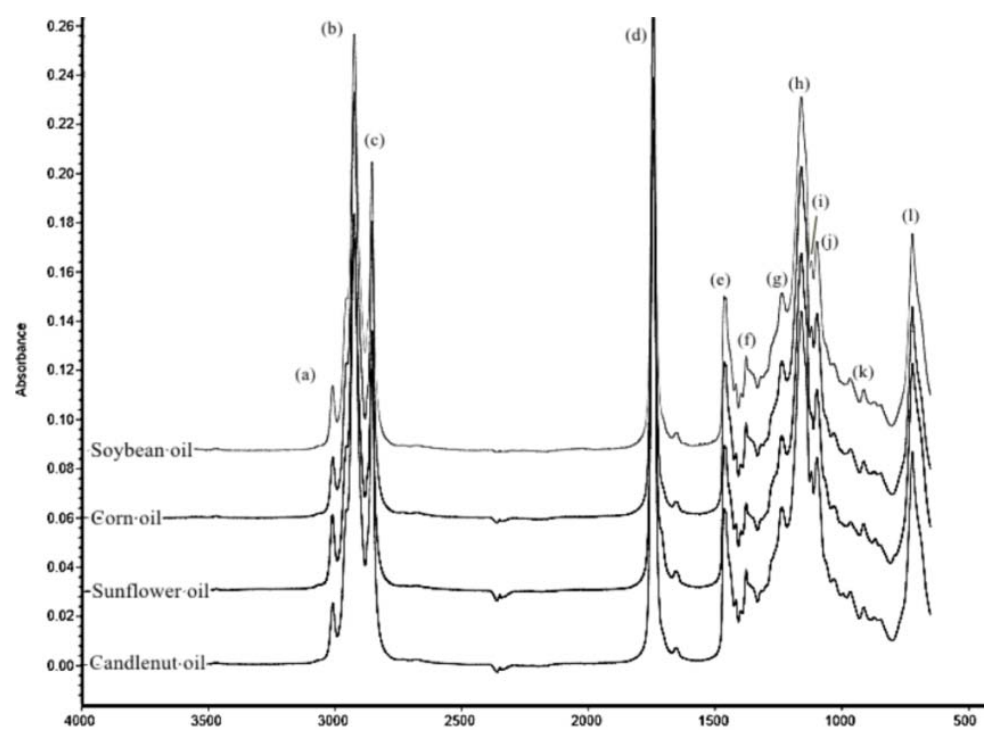

Fig. 2: FTIR spectra of candlenut oil, sunflower oil, corn oil and soybean oil scanned using FTIR spectroscopy at mid infrared region $\left(4000-650 \mathrm{~cm}^{-1}\right)$

Table 1: The performance of multivariate calibrations along with wavenumbers and FTIR spectral treatments for analysis of candlenut oil $(\mathrm{CnO})$ in the binary mixtures with sunflower oil, soybean oil, and corn oil

\begin{tabular}{|c|c|c|c|c|c|c|c|c|}
\hline \multirow{2}{*}{$\begin{array}{l}\text { Oil } \\
\text { adulterans }\end{array}$} & \multirow{2}{*}{$\begin{array}{l}\text { Multivariate } \\
\text { calibration }\end{array}$} & \multirow{2}{*}{$\begin{array}{l}\text { Wave-numbers } \\
\left(\mathrm{cm}^{-1}\right)\end{array}$} & \multirow[t]{2}{*}{ Treatments* } & \multirow[t]{2}{*}{ Factor } & \multicolumn{2}{|c|}{ Calibration } & \multicolumn{2}{|c|}{ Validation } \\
\hline & & & & & $\mathbf{R}^{2}$ & RMSEC & $\mathbf{R}^{2}$ & RMSEP \\
\hline \multirow[t]{18}{*}{ Sunflower oil } & \multirow[t]{9}{*}{ PCR } & \multirow[t]{3}{*}{$4000-650$} & Normal & 10 & 0.9984 & 1.72 & 0.9982 & 2.28 \\
\hline & & & Der. 1 & 10 & 0.9985 & 1.71 & 0.9986 & 2.46 \\
\hline & & & Der. 2 & 10 & 0.9910 & 4.12 & 0.9904 & 7.51 \\
\hline & & \multirow[t]{3}{*}{$3100-2800$} & Normal & 10 & 0.9990 & 1.52 & 0.9985 & 1.56 \\
\hline & & & Der. 1 & 10 & 0.9978 & 2.78 & 0.9992 & 1.50 \\
\hline & & & Der. 2 & 10 & 0.9961 & 2.99 & 0.9966 & 2.53 \\
\hline & & \multirow[t]{3}{*}{$1500-1000$} & Normal & 10 & 0.9987 & 1.54 & 0.9975 & 2.66 \\
\hline & & & Der. 1 & 10 & 0.9986 & 1.65 & 0.9977 & 2.44 \\
\hline & & & Der. 2 & 10 & 0.9978 & 2.04 & 0.9981 & 2.24 \\
\hline & \multirow[t]{9}{*}{ PLS } & \multirow[t]{3}{*}{$4000-650$} & Normal & 6 & 0.9989 & 1.47 & 0.9976 & 2.56 \\
\hline & & & Der. 1 & 3 & 0.9995 & 0.99 & 0.9984 & 2.49 \\
\hline & & & Der. 2 & 7 & 0.9999 & 0.06 & 0.9926 & 6.98 \\
\hline & & \multirow[t]{3}{*}{$3100-2800$} & Normal & 5 & 0.9989 & 1.58 & 0.9983 & 1.72 \\
\hline & & & Der. 1 & 3 & 0.9987 & 1.71 & 0.9987 & 1.65 \\
\hline & & & Der. 2 & 2 & 0.9964 & 2.87 & 0.9960 & 2.76 \\
\hline & & \multirow[t]{3}{*}{$1500-1000$} & Normal & 6 & 0.9989 & 1.47 & 0.9976 & 2.56 \\
\hline & & & Der. 1 & 2 & 0.9974 & 2.20 & 0.9980 & 2.41 \\
\hline & & & Der. 2 & 6 & 0.9999 & 0.499 & 0.9978 & 2.51 \\
\hline \multirow[t]{12}{*}{ Soybean oil } & \multirow[t]{6}{*}{ PCR } & \multirow{3}{*}{$\begin{array}{l}1765-1625 ; 839- \\
663\end{array}$} & Normal & 10 & 0.9994 & 1.05 & 0.9989 & 1.63 \\
\hline & & & Der. 1 & 10 & 0.9958 & 2.77 & 0.9970 & 3.11 \\
\hline & & & Der. 2 & 10 & 0.9705 & 7.29 & 0.9435 & 11.8 \\
\hline & & \multirow{3}{*}{$956-899$} & Normal & 10 & 0.9981 & 1.86 & 0.9981 & 2.15 \\
\hline & & & Der. 1 & 10 & 0.9960 & 2.70 & 0.9963 & 3.35 \\
\hline & & & Der. 2 & 10 & 0.8514 & 15.9 & 0.8424 & 17.7 \\
\hline & \multirow[t]{6}{*}{ PLS } & \multirow{3}{*}{$\begin{array}{l}1765-1625 ; 839- \\
663\end{array}$} & Normal & 5 & 0.9996 & 0.867 & 0.9990 & 1.61 \\
\hline & & & Der. 1 & 5 & 0.9994 & 1.02 & 0.9968 & 2.73 \\
\hline & & & Der. 2 & 7 & 0.9986 & 1.59 & 0.9845 & 6.50 \\
\hline & & \multirow[t]{3}{*}{$956-899$} & Normal & 2 & 0.9978 & 1.99 & 0.9979 & 2.14 \\
\hline & & & Der. 1 & 1 & 0.9953 & 2.92 & 0.9966 & 3.47 \\
\hline & & & Der. 2 & 9 & 0.9911 & 4.03 & 0.9682 & 7.78 \\
\hline Corn oil & PCR & $970-857$ & Normal & 10 & 0.9968 & 2.11 & 0.9883 & 4.83 \\
\hline & & & Der. 1 & 10 & 0.9867 & 4.25 & 0.9839 & 5.08 \\
\hline & & & Der. 2 & 10 & 0.7636 & 16.9 & 0.6569 & 21.6 \\
\hline & & $970-838 ; 1125-$ & Normal & 10 & 0.9959 & 2.32 & 0.9946 & 4.39 \\
\hline & & 1111 & Der. 1 & 10 & 0.9899 & 3.63 & 0.9913 & 4.55 \\
\hline & & & Der. 2 & 10 & 0.9766 & 5.50 & 0.9692 & 9.70 \\
\hline & PLS & $970-857$ & Normal & 3 & 0.9959 & 2.38 & 0.9958 & 2.63 \\
\hline & & & Der. 1 & 9 & 0.9992 & 1.04 & 0.9820 & 5.65 \\
\hline & & & Der. 2 & 3 & 0.9483 & 8.31 & 0.7683 & 18.5 \\
\hline & & $970-838 ; 1125-$ & Normal & 4 & 0.9939 & 2.82 & 0.9927 & 4.36 \\
\hline & & 1111 & Der. 1 & 5 & 0.9975 & 1.81 & 0.9909 & 5.21 \\
\hline & & & Der. 2 & 7 & 0.9985 & 1.38 & 0.9839 & 8.58 \\
\hline
\end{tabular}

*treatments marked with bold are selected for the modelling calibration and validation 


\section{Quantitative analysis of candlenut oil}

Quantitative analysis of candlenut oil ( $\mathrm{CnO}$ ) in binary mixture with SFO, SyO and CO was facilitated with multivariate calibrations of principle component regression (PCR) and partial least square regression (PLSR). Both regressions are based on inverse regression in which concentrations in y-axis are modelled as function of combination of variables of absorbances called as principle components in x-axis (Miller and Miller, 2010). Using these multivariate calibrations, several statistical parameters namely coefficient determination $\left(R^{2}\right)$, root mean square error of calibration (RMSEC) and root mean square error of prediction (RMSEP) were used for evaluation of calibration and validation models. In this study, the models was optimized by selecting the best FTIR spectral regions and spectral treatments (derivatization) capable of providing the highest $\mathrm{R}^{2}$ value and the lowest RMSEC and RMSEP.

Table 1 compiled the performance of PCR and PLSR for quantification of $\mathrm{CnO}$ in SFO, CO and SyO in terms of $\mathrm{R}^{2}$, RMSEC, and RMSEP values using several wavenumbers region and spectral treatments (normal, first derivate and second derivate). Based on highest $\mathrm{R}^{2}$ either in calibration and validation samples and lowest RMSEC and RMSEP values obtained, $\mathrm{CnO}$ in SFO was quantified using PCR at wavenumbers region of 3100$2800 \mathrm{~cm}^{-1}$ using FTIR normal spectra With R $\mathrm{R}^{2}$ calibration of $0.9990, \mathrm{R}^{2}$ validation of 0.997 , RMSEC of $1.52 \%$ and RMSEP of $1.56 \%$. In addition, $\mathrm{CnO}$ in SyO was analyzed using PLSR with normal spectra in the combined wavenumbers of $1765-1625$ and $839-663 \mathrm{~cm}^{-1}$. Finally, the normal spectra at wavenumbers region of 970-857 was selected for quantification of $\mathrm{CnO}$ in binary mixture with $\mathrm{CO}$.
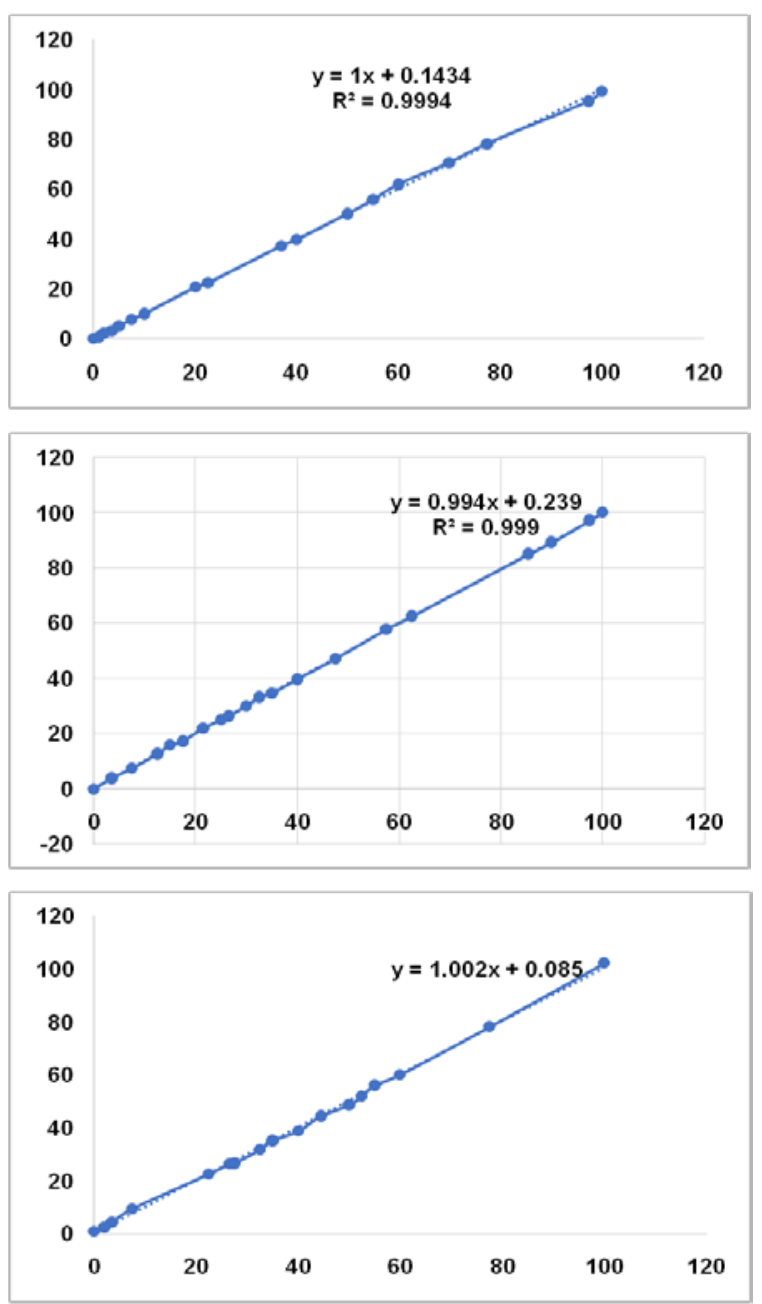

Fig. 3: The calibration model describing the relationship between actual values and FTIR predicted values of candlenut oil in not sunflower oil (top), soybean oil (middle), and corn oil (down)
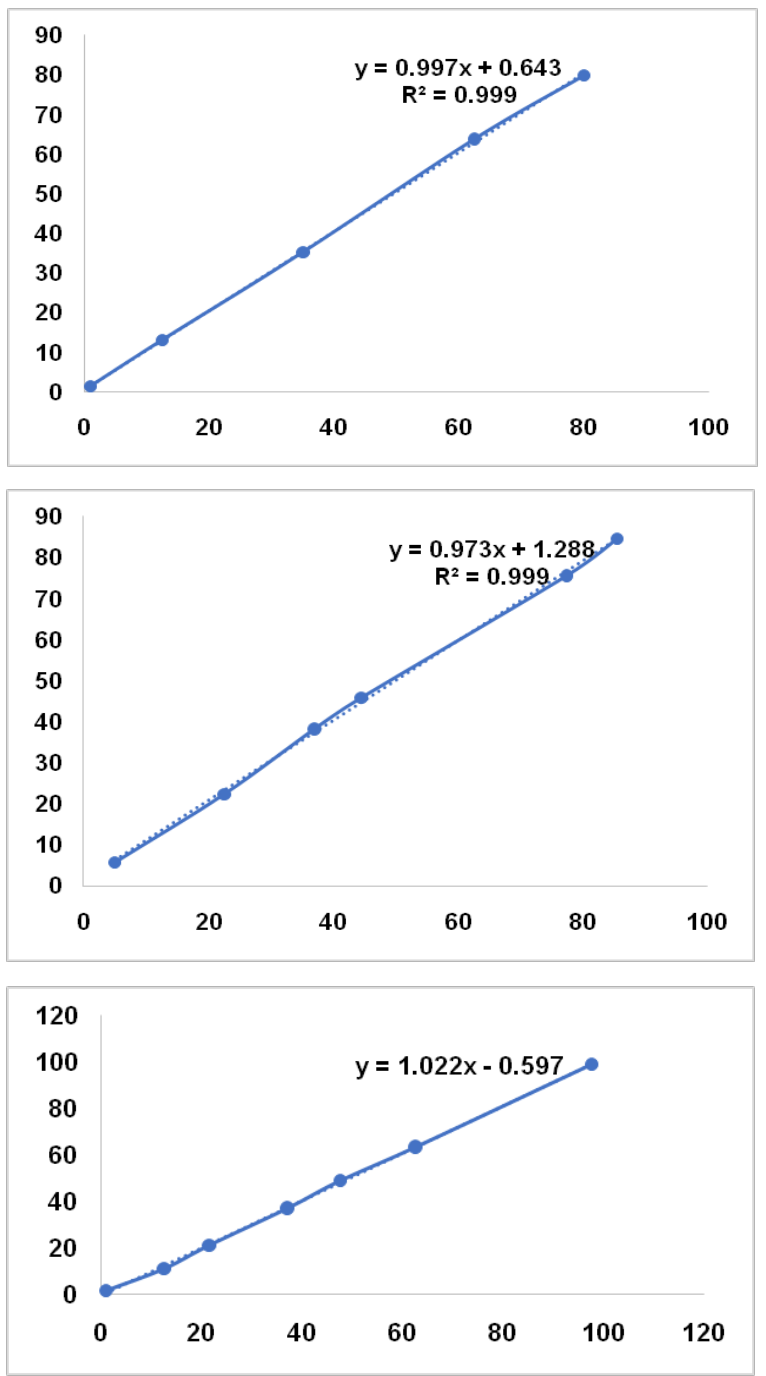

Fig. 4: The calibration model describing the relationship between actual values and FTIR predicted values of candlenut oil in not sunflower oil (top), soybean oil (middle), and corn oil (down)

Fig. 3 and fig. 4 revealed the relationship between actual values and FTIR predicted values of $\mathrm{CnO}$ in $\mathrm{SFO}, \mathrm{SyO}$ and $\mathrm{CO}$ along with its equations in calibration and validation models, respectively. The residual point (the difference between actual and predicted) was around zero, indicating that no systematic errors were observed during modelling, therefore the calibration and validation models developed were reliable for quantification of $\mathrm{CnO}$ in the mixture mixtures with SFO, SyO and CO.

\section{Discriminant analysis}

In order to make classification between authentic $\mathrm{CnO}$ and $\mathrm{CnO}$ adulterated with other vegetable oils (SFO, SyO and CO) discriminant analysis (DA) was used. DA is one of supervised pattern recognition technique based on linear discriminant function, which is a linear combination of the original measured variables [26]. During classification using DA, the absorbances at selected wavenumbers regions was chosen such a way that they provide clear separation between two-classes of samples. Fig. 5 revealed the Coomans plot for discrimination between $\mathrm{CnO}$ and $\mathrm{CnO}$ adulterated with SFO (using absorbance at wavenumbers of 3100-2800 $\mathrm{cm}^{-1}$ ), SyO (at 1765-1625 $\mathrm{cm}^{-1}$ and 839-663 $\mathrm{cm}^{-1}$ ), and with CO (at wavenumbers of $1125-1111 \mathrm{~cm}^{-1}$ ). The accuracy levels of $100 \%$ were obtained meaning that misclassification did not occur. Sometimes, if the studied oils have close similarity between authentic and adulterated oils, misclassification may occur, and then the model of DA must be re-optimized. 

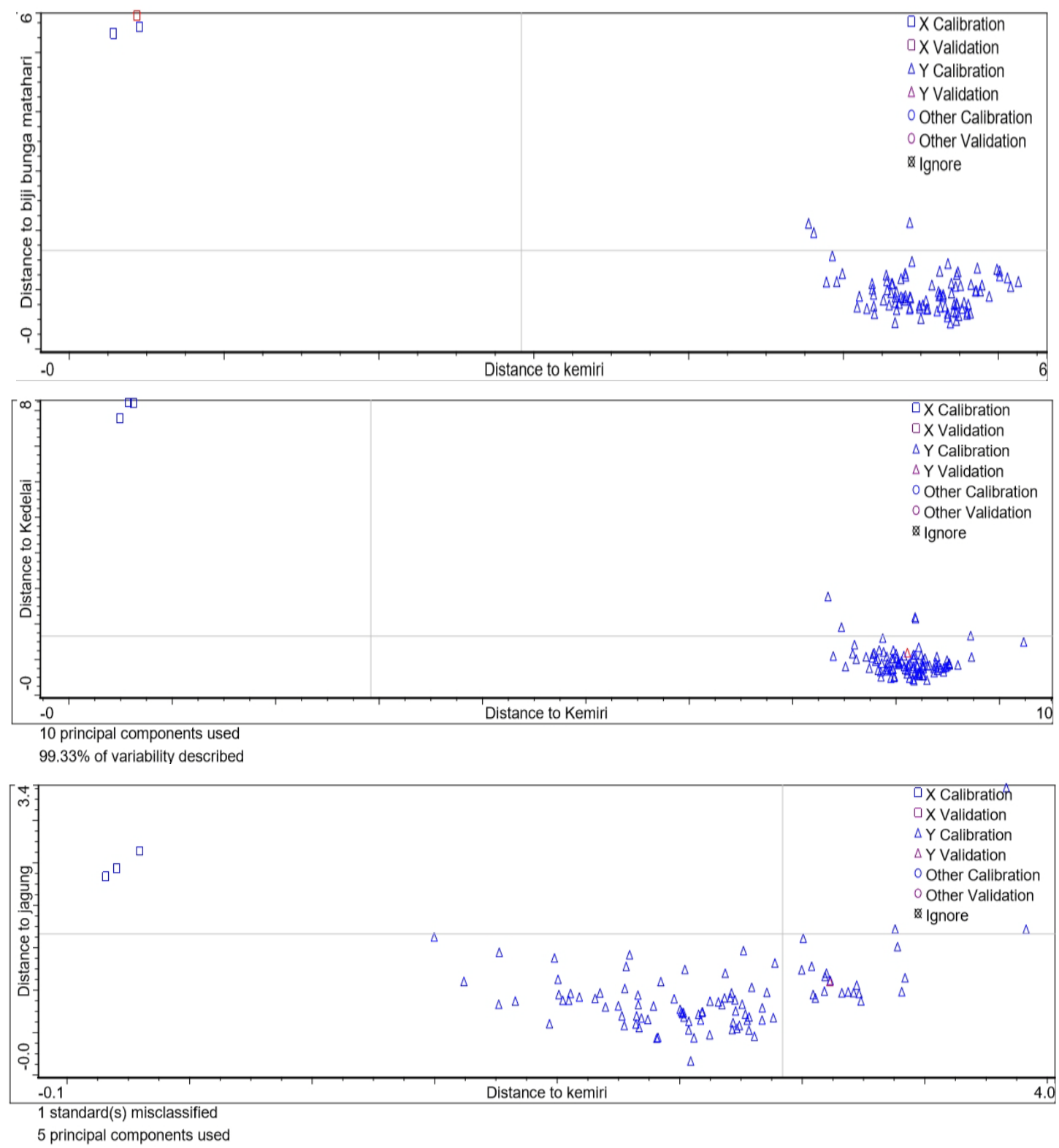

Fig. 5: The Coomans plot for the classification of candlenut oil $(\square)$ and candlenut oil adulterated with other oils)( nam ely sun flower oil (top), soybean oil (middle), and corn oil (down)

\section{CONCLUSION}

The combination of FTIR spectroscopy with chemometrics of multivariate calibrations (PCR and PLSR) and discriminant analysis using absorbance values as variables at optimized wavenumbers regions are powerful analytical technique for authentication analysis of candlenut oil $(\mathrm{CnO})$ from sunflower oil, soybean oil, and corn oil. Discriminant analysis allow rapid classification between $\mathrm{CnO}$ and $\mathrm{CnO}$ adulterated with other vegetable oils with accuracy levels of $100 \%$. The developed method was reliable, rapid, and ease in sample preparation, which make it as rapid tools for quality control of edible oils.

\section{ACKNOWLEDGEMENT}

The Ministry of Research, Technology and Higher Education, Republic Indonesia are acknowledged for partial financial assistance during this study via Hibah Penelitian Unggulan Perguruan Tinggi (PUPT) 2017.

\section{AUTHORS CONTRIBUTIONS}

FY and AR performed research activities and prepared manuscript. SR and AR designed research, analyzed data, and made critical thinking on manuscript.

\section{CONFLICTS OF INTERESTS}

All authors have none to declare

\section{REFERENCES}

1. Krisnawati H, Kallio M, Kanninen M.Aleurites moluccana (L.) Willd: Ecology, silviculture and productivity. CIFOR, Bogor; 2011.

2. Elevitch CR, Manner HI. Traditional tree initiative: species profiles for Pacific islands agroforestry-ecological, economic, and cultural renewal. Agroforestry. Available from: http://www.agroforestry.net/tti/Aleurites-kukui.pdf. [Last accessed on 06 May 2006]

3. Subroto E, Widjojokusumo E, Veriansyah B, Tjandrawinata RR. Supercritical $\mathrm{CO}_{2}$ extraction of candlenut oil: process optimization using taguchi orthogonal array and physicochemical properties of the oil. J Food Sci Technol 2017;54:1286-92.

4. Shukla AK, Dixit AK, Singh RP. Detection of adulteration in edible oils. J Oleo Sci 2005;6:317-24.

5. Indriyani L, Riyanto S, Rohman A. Physico-chemical characterization of avocado (Persea americana Mill.) oil from 
three indonesian avocado cultivars. Res J Med Plant 2016;10:67-78.

6. Mansor TST, Che Man YB, Rohman A. Application of fast chromatography and fourier transform infrared spectroscopy for analysis of lard adulteration in virgin coconut oil. Food Anal Methods 2011;4:365-72.

7. Bajoub A, Medina Rodriguez S, Gomez Romero M, Ajal E, Bagur Gonzalez MG, Fernandez Gutierrez A, et al. Assessing the varietal origin of extra-virgin olive oil using liquid chromatography fingerprints of phenolic compound, data fusion and chemometrics. Food Chem 2017;215:245-55.

8. Flores G, Ruiz Del Castillo ML, Herraiz M, Blanch GP. Study of the adulteration of olive oil with hazelnut oil by on-line coupled high performance liquid chromatographic and gas chromatographic analysis of filbertone. Food Chem 2006;97:742-9.

9. Jafari M, Kadivar M, Keramat J. Detection of adulteration in iranian olive oils using instrumental (GC, NMR, DSC) methods. J Am Oil Chem Soc 2009;86:103-10.

10. Godoy Caballeroa MP, Culzoni MJ, Galeano Diaz T, Acedo Valenzuela MI. Novel combination of non-aqueous capillary electrophoresis and multivariate curve resolution-alternating least squares to determine phenolic acids in virgin olive oil. Anal Chim Acta 2013;763:11-9.

11. Nurrulhidayah AF, Rohman A, Arief Salleh R, Amin I, Shuhaimi $\mathrm{M}$, Farahwahida MY, et al. Authentication of butter from lard using high-resolution of NMR spectroscopy for halal authentication. Int J Food Prop 2017;20:2147-56.

12. Kamble VV, Gaikwad NB. Fourier transform infrared spectroscopy spectroscopic studies in Embelia ribes Burm. F.: A vulnerable medicinal plant. Asian J Pharm Clin Res 2016;9:41-7.

13. Nugrahani I, Dillen N. Rapid assay development of diclofenac sodium coated tablet assay using FTIR compared to HPLC method. Int J Appl Pharm 2018;10:43-50.

14. Nugrahani I, Khalida FN. Green method for acetaminophen and ibuprofen simultaneous assay in the combination tablet using FTIR. Int J Appl Pharm 2018;10:77-83.

15. Ramos Gomez S, Busto MD, Albillos SM, Ortega N. Novel qPCR systems for olive (Olea europaea L.) authentication in oils and food. Food Chem 2016;194:447-54.
16. Rohman A. The use of infrared spectroscopy in combination with chemometrics for quality control and authentication of edible fats and oils: a review. Appl Spectros Rev 2017;52:589-604.

17. Rohman A, Che Man YB, Mohd Yusof F. The use of FTIR spectroscopy and chemometrics for rapid authentication of extra virgin olive oil. J Am Oil Chem Soc 2014;91:207-13.

18. Lerma Garcıa MJ, Ramis Ramos G, Herrero Martınez JM, SimoAlfonso EF. Authentication of extra virgin olive oils by fouriertransform infrared spectroscopy. Food Chem 2010;118:78-83.

19. Rohman A, Wibowo D, Sudjadi, Lukitaningsih L, Rosman AS Use of fourier transform infrared spectroscopy in combination with partial least square for authentication of black seed oil. Int J Food Prop 2015;18:775-84.

20. Lumakso FA, Rohman A, Handoy M, Riyanto S, Mohd Yusuf F. Detection and quanffication of soybean and corn oils as adulterants in avocado oil using Fourier transform mid infrared (FT-MIR) spectroscopy aided with multivariate calibration. J Teknologi 2015;77:251-60.

21. Rohman A, Windarsih A, Riyanto S, Sudjad, Ahmad SAS, Rosman AS, et al. Fourier transform infrared spectroscopy combined with multivariate calibrations for the authentication of avocado oil. Int J Food Prop 2016;19:680-7.

22. Nurrulhidayah AF, Che Man YB, Rohman A. FTIR spectroscopy combined with chemometric for analysis of sesame oil adulterated with corn oil. Int J Food Prop 2014;17:1275-82.

23. Manaf MA, Che Man YB, Hamid NSA, Ismail A, Syahariza ZA. Analysis of adulteration of virgin coconut oil by palm kernel olein using fourier transform infrared spectroscopy. J Food Lipids 2007;14:111-21.

24. Che Man YB, Marina AM, Rohman A, Al-Kahtani HA, Norazura 0 . A fourier transform infrared spectroscopy method for analysis of palm oil adulterated with lard in pre-fried french fries. Int J Food Prop 2014;17:354-62.

25. Norulaini N, Budi RS, Omar A, Zaidul MLS, Omar MAK. Major chemical constituents of candlenut oil extract using supercritical carbon dioxide. Malaysian J Pharm Sci 2004;2:61-72.

26. Che Man YB, Rohman A, Mansor TST. Differentiation of lard from other edible oils by means of fourier transform infrared spectroscopy and chemometrics. J Am Oil Chem Soc 2011;88:187-92. 